ARTICLE

\title{
Photobactericidal activity activated by thiolated gold nanoclusters at low flux levels of white light
}

Gi Byoung Hwang (10 1, He Huang², Gaowei Wu (10 2, Juhun Shin (1) 1, Andreas Kafizas (10 3,4, Kersti Karu (1) ${ }^{1}$, Hendrik Du Toit ${ }^{2}$, Abdullah M. Alotaibi ${ }^{1}$, Layla Mohammad-Hadi ${ }^{5}$, Elaine Allan (1) ${ }^{6}$, Alexander J. MacRobert (10 ${ }^{5}$, Asterios Gavriilidis (D) ${ }^{2}$ \& Ivan P. Parkin ${ }^{1 凶}$

The emergence of antibiotic resistant bacteria is a major threat to the practice of modern medicine. Photobactericidal agents have obtained significant attention as promising candidates to kill bacteria, and they have been extensively studied. However, to obtain photobactericidal activity, an intense white light source or UV-activation is usually required. Here we report a photobactericidal polymer containing crystal violet ( $C V$ ) and thiolated gold nanocluster ( $\left[\mathrm{Au}_{25}(\mathrm{Cys})_{18}\right]$ ) activated at a low flux levels of white light. It was shown that the polymer encapsulated with $\mathrm{CV}$ do not have photobactericidal activity under white light illumination of an average 312 lux. However, encapsulation of $\left[\mathrm{Au}_{25}(\mathrm{Cys})_{18}\right]$ and $\mathrm{CV}$ into the polymer activates potent photobactericidal activity. The study of the photobactericidal mechanism shows that additional encapsulation of $\left[\mathrm{Au}_{25}(\mathrm{Cys})_{18}\right]$ into the $\mathrm{CV}$ treated polymer promotes redox reactions through generation of alternative electron transfer pathways, while it reduces photochemical reaction type-II pathways resulting in promotion of hydrogen peroxide $\left(\mathrm{H}_{2} \mathrm{O}_{2}\right)$ production.

\footnotetext{
${ }^{1}$ Materials Chemistry Research Centre, Department of Chemistry, University College London, 20 Gordon Street, London WC1H OAJ, UK. ${ }^{2}$ Department of Chemical Engineering, University College London, Torrington Place, London WC1E 7JE, UK. ${ }^{3}$ Department of Chemistry, Imperial College London, Molecular Science Research Hub, White City Campus, 80 Wood Lane, London W12 OBZ, UK. ${ }^{4}$ Grantham Institute, Imperial College London, Exhibition Road, London SW7 2AZ, UK. ${ }^{5}$ UCL Division of Surgery and Interventional Science, Royal Free Campus, Rowland Hill Street, London NW3 2PF, UK. ${ }^{6}$ Department of

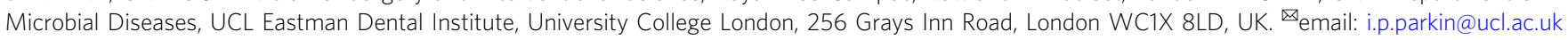


$\mathrm{T}$ he discovery of antibiotics in the early 20th Century revolutionised the treatment of bacterial infections but after several decades of overuse, the evolution of antibiotic resistant bacteria is a major threat to the practice of modern medicine ${ }^{1-7}$. Surfaces in healthcare facilities used to be considered not to have an effect on the spread of infection ${ }^{8}$. Recent studies have reported that bacteria-contaminated surfaces make a significant contribution to the incidence of healthcare associated infections $^{8-13}$, and that repeated cleaning/disinfection of the contaminated surfaces, which is commonly performed in healthcare facilities, is not always sufficient to remove pathogens from surfaces. For example, $27 \%$ of surfaces in rooms were still contaminated by bacteria after four complete cleaning cycles with disinfectant ${ }^{14-16}$.

Photobactericidal agents have gained significant attention as promising candidates to kill bacteria and keep surfaces sterile. Toluidine blue $\mathrm{O}(\mathrm{TBO})$, methylene blue (MB) and crystal violet (CV) are widely used for surgical and biological stains and wound disinfection, and are known to have photobactericidal activity ${ }^{17}$. When the agents are exposed to a bright visible light source, they are photoexcited and induce reactive oxygen species (ROS), killing bacteria through damage to the cell membrane and $\mathrm{DNA}^{18-22}$. Due to their photobactericidal property, and ease of use, the photobactericidal agents were used to treat infections of blood products and oral infections, and are also effective at killing antibiotic resistant bacteria ${ }^{22}$.

It has been shown that zinc oxide $(\mathrm{ZnO})$, silver $(\mathrm{Ag})$, and gold $(\mathrm{Au})$ nanoparticles $(\mathrm{NPs})$ in combination with $\mathrm{TBO}, \mathrm{CV}$, and $\mathrm{MB}$ produce a synergistic bactericidal effect. This effect was most pronounced using intense light sources such as lasers or bright light of white light source $\left(1000-10000 \text { lux; } 0.15-1.5 \mathrm{~mW} \mathrm{~cm}^{-2}\right)^{23-28}$. For gold NPs, there is a size effect, where the smallest NPs tested (2-20 $\mathrm{nm}$ ) showed the greatest promotion of the dyes' bactericidal properties $^{23-29}$. The 2-nm Au NPs are at the crossover point between the quantum description of matter and a molecular cluster approach $^{30}$.

Gold clusters consist of a small number of atoms, and its typical size is less than $2 \mathrm{~nm}^{31,32}$. A Au cluster has discrete physico-chemical properties compared to larger Au NPs. In contrast to Au NPs, the cluster does not show surface plasmon resonance, and the electronic band structure of the cluster is different from Au NPs, where the band structure of Au NPs is typically continuous whereas $\mathrm{Au}$ nanoclusters form a discontinuous band structure with discrete energy levels ${ }^{33}$.

The motivation herein was to see if discrete molecular gold clusters could promote a greater synergistic effect in enhancing the photobactericidal effect of $\mathrm{CV}$ dye. To evaluate this, we synthesize $\left[\mathrm{Au}_{25}(\mathrm{Cys})_{18}\right]$ clusters via a scalable microfluidic approach and incorporated them with $\mathrm{CV}$ into a polymer surface to test its bactericidal properties. Surprisingly, this cluster promotes bactericidal activity at very low levels of white light. We suggest that the presence of $\left[\mathrm{Au}_{25}(\mathrm{Cys})_{18}\right]$ promotes redox reactions by generating an electron transfer pathway from $\mathrm{CV}$ to the cluster, resulting in enhanced $\mathrm{H}_{2} \mathrm{O}_{2}$ formation and bactericidal activity.

\section{Results and discussions}

To continuously synthesize $\left[\mathrm{Au}_{25}(\mathrm{Cys})_{18}\right]$, a microfluidic segmented flow system that consisted of a tube-in-tube membrane contactor system and coil flow inverter reactor was used (Supplementary Fig. 1). In this system, $\mathrm{Au}$ (I) solution containing 3 $\mathrm{mM}$ cysteine was mixed with CO-saturated heptane, which was prepared by the tube-in-tube; The mixture passed through a coil flow inverter reactor at $80^{\circ} \mathrm{C}$. In the reactor inverter, $\left[\mathrm{Au}_{25}(\mathrm{Cys})_{18}\right]$ was continuously synthesized with residence time of $3 \mathrm{~min}$. The $\left[\mathrm{Au}_{25}(\mathrm{Cys})_{18}\right]$ solution was stored at room temperature overnight. After that, an organic layer, formed by heptane, on the top of the solution was removed. As shown below, this process exclusively formed $\left[\mathrm{Au}_{25}(\mathrm{Cys})_{18}\right]$ clusters with no evidence of larger or smaller clusters.

The UV-Vis spectrum of the $\left[\mathrm{Au}_{25}(\mathrm{Cys})_{18}\right]$ solution was measured from 300 to $900 \mathrm{~nm}$. As shown in Fig. 1a, the nanoclusters gave multiple absorption peaks at 400, 450, 670 and $780 \mathrm{~nm}$ which are in agreement with the absorbance features of thiolated $\mathrm{Au}_{25}$ clusters reported previously ${ }^{34}$. It was confirmed that the concentration of synthesized $\left[\mathrm{Au}_{25}(\mathrm{Cys})_{18}\right]$ was about $0.12 \mathrm{mM} \quad\left(7.2 \times 10^{16}\right.$ $\left[\mathrm{Au}_{25}(\mathrm{Cys})_{18}\right]$ clusters $\left.\mathrm{mL}^{-1}\right)$. ESI-MS was used to determine the molecular composition of $\left[\mathrm{Au}_{25}(\mathrm{Cys})_{18}\right]$. As shown in Fig. $1 \mathrm{~b}$, it was observed that the most intense set of peaks were at $\mathrm{m} / \mathrm{z} \sim 2361.4$ over a range of $m / z$ 1500-5200, and Fig. 1c shows that the base peak at $m /$ $z 2361.4$ (peak \#1) was accompanied with a group of similar small peaks (peak \#2 to \#7) corresponding to $\mathrm{H}^{+}$dissociation and $\mathrm{Na}^{+}$ coordination to $\left[\mathrm{Au}_{25}(\mathrm{Cys})_{18}\right]$. Isotope pattern analysis of peak $\# 1$ showed that the peak spacing between ${ }^{12} \mathrm{C}$ and ${ }^{13} \mathrm{C}$ was about 0.33 indicating that $\left[\mathrm{Au}_{25}(\mathrm{Cys})_{18}\right]$ carried three negative charges resulting in the generation of $\left[\mathrm{Au}_{25}(\mathrm{Cys})_{18}-3 \mathrm{H}\right]^{3-}$ with molecular weight (MW) of 7083.2 Da (Fig. 1d). Other ionised species (\#2 to \#7) are (\#2) $\left[\mathrm{Au}_{25}(\mathrm{Cys})_{18}-4 \mathrm{H}+\mathrm{Na}\right]^{3-}$ (MW 7106.1), (\#3) $\left[\mathrm{Au}_{25}(\mathrm{Cys})_{18}-5 \mathrm{H}\right.$ $+2 \mathrm{Na}]^{3-}(\mathrm{MW} 7128.1 \mathrm{Da}),(\# 4)\left[\mathrm{Au}_{25}(\mathrm{Cys})_{18}-6 \mathrm{H}+3 \mathrm{Na}\right]^{3-}(\mathrm{MW}$ $7150.2 \mathrm{Da}),(\# 5)\left[\mathrm{Au}_{25}(\mathrm{Cys})_{18}-7 \mathrm{H}+4 \mathrm{Na}\right]^{3-}(\mathrm{MW} 7172.2 \mathrm{Da}),(\# 6)$ $\left[\mathrm{Au}_{25}(\mathrm{Cys})_{18}-8 \mathrm{H}+5 \mathrm{Na}\right]^{3-}(\mathrm{MW} 7194.1 \mathrm{Da})$ and $(\# 7)\left[\mathrm{Au}_{25}(\mathrm{Cys})_{18}\right.$ $9 \mathrm{H}+6 \mathrm{Na}]^{3-}(\mathrm{MW} 7216.2 \mathrm{Da})$. The ionised species and isotope patterns containing \#1 to \#7 were identical to those obtained by theoretical simulation (Fig. 1d and Supplementary Fig. 2). Additionally, other sets of cluster peaks were observed at $\mathrm{m} / \mathrm{z} \sim 1808.6$, 2411, and 3542.6, indicating 2-, 3- and 4- charged gas phase ions. All peaks corresponded to $\left[\mathrm{Au}_{25}(\mathrm{Cys})_{18}\right]$, indicating that no other clusters were formed ${ }^{35}$. TEM (Fig. 1a inset) shows that the size of the $\left[\mathrm{Au}_{25}(\mathrm{Cys})_{18}\right]$ clusters was $<2 \mathrm{~nm}^{36}$.

A swell-encapsulation-shrink process was employed to produce photobactericidal silicone. Fluorescence microscopy, UV-Vis spectroscopy and XPS confirmed that after the treatment, CV molecules and $\left[\mathrm{Au}_{25}(\mathrm{Cys})_{18}\right]$ clusters penetrated into the polymer matrix (Supplementary Fig. 3). As shown in Fig. 2a, after $\left[\mathrm{Au}_{25}(\mathrm{Cys})_{18}\right]$ or cysteine treatment, the silicone substrate maintained its colour, while $\mathrm{CV}$ treatment changed from white to violet. The colour of the polymer containing CV\& $\left[\mathrm{Au}_{25}(\mathrm{Cys})_{18}\right]$ was more intense than the sample with $\mathrm{CV}$ alone. Figure $2 \mathrm{~b}$ shows UV-vis absorbance spectra of the control and treated samples at a wavelength of $400-800 \mathrm{~nm}$. All of the CV-treated polymers have a main absorbance at $595 \mathrm{~nm}$ with a shoulder peak at $541 \mathrm{~nm}$. The absorbance of $\left[\mathrm{Au}_{25}(\mathrm{Cys})_{18}\right]$ encapsulated sample was broader and of higher intensity compared to the sample with $\mathrm{CV}$ alone. Of materials used for the encapsulation, $\mathrm{CV}$ is the only material containing chlorine $(\mathrm{Cl})$. Thus, a change in the weight percentage ( $w \mathrm{t} \%$ ) of $\mathrm{Cl}$ was determined before and after additional encapsulation of $\left[\mathrm{Au}_{25}(\mathrm{Cys})_{18}\right]$ by $\mathrm{X}$-ray fluorescence spectroscopy (XRF). $\mathrm{Cl} \mathrm{wt} \%$ in $\mathrm{CV} \&\left[\mathrm{Au}_{25}\left(\mathrm{Cys}_{18}\right)\right]$ polymer was 1.8 times higher than the polymer containing $\mathrm{CV}$ alone. This was similar with the increase of light absorbance of the material at $595 \mathrm{~nm}$ after additional encapsulation of $\left[\mathrm{Au}_{25}(\mathrm{Cys})_{18}\right]$ into the $\mathrm{CV}$-treated polymer. This showed that addition of $\left[\mathrm{Au}_{25}(\mathrm{Cys})_{18}\right]$ enhanced CV impregnation into the polymer. The image analysis of sliced polymers supports the increase of $\mathrm{CV}$ uptake by $\left[\mathrm{Au}_{25}\left(\mathrm{Cys}_{18)}\right]\right.$ (Supplementary Fig. 4). We speculate that this is because negatively charged $\left[\mathrm{Au}_{25}(\mathrm{Cys})_{18}\right]$ (zeta potential of $\left[\mathrm{Au}_{25}(\mathrm{Cys})_{18}\right]$ solution: $\left.-31.8 \mathrm{mV}\right)$ attracts more $\mathrm{CV}^{+}$during the encapsulation process ${ }^{37}$.

Staphylococcus aureus and Escherichia coli are common pathogens in healthcare facilities and can cause a range of infections from local skin and catheter-related infections to sepsis 

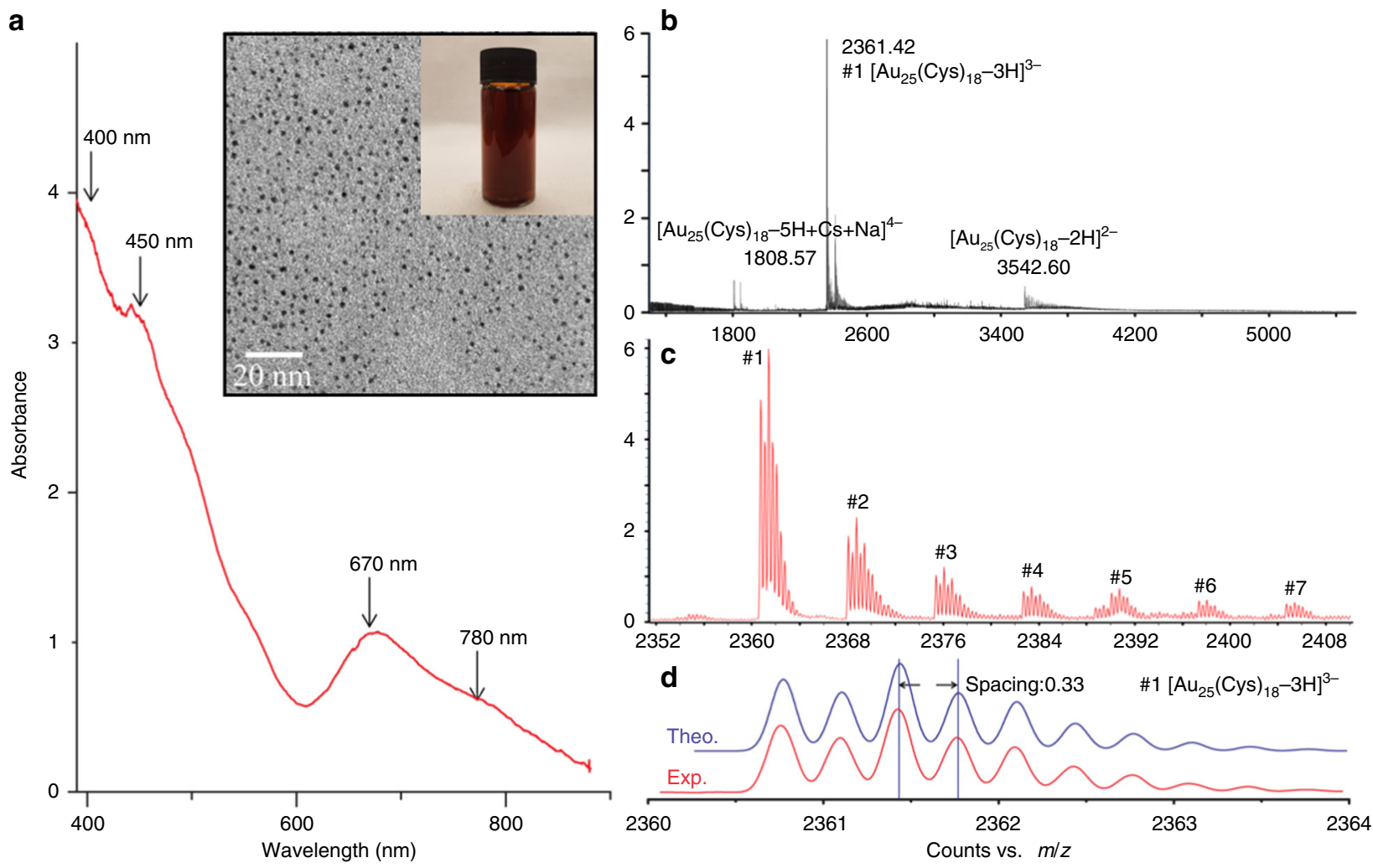

Fig. 1 Characterization of synthesized $\left[\mathbf{A u}_{\mathbf{2 5}}(\mathbf{C y s})_{\mathbf{1 8}}\right]$. a UV-Vis spectrum of $\left[\mathrm{Au}_{25}(\mathrm{Cys})_{18}\right]$ solution (inset shows the picture and TEM image of $\left[\mathrm{Au}_{25}(\mathrm{Cys})_{18}\right]$ solution). b, c ESI-mass spectra of $\left[\mathrm{Au}_{25}(\mathrm{Cys})_{18}\right]$. d Comparison between theoretical and experimental isotope pattern of \#1 peak.

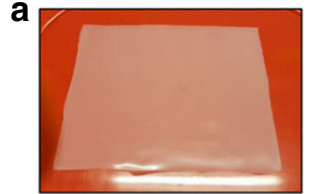

Control

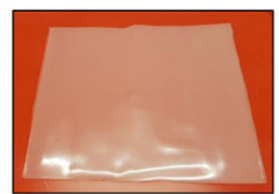

$\left[\mathrm{Au}_{25}(\mathrm{Cys})_{18}\right]$ only

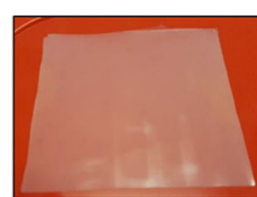

Cysteine only

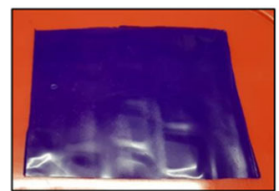

CV only

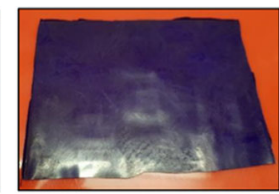

$\mathrm{CV}$ and $\left[\mathrm{Au}_{25}(\text { Cys })_{18}\right]$

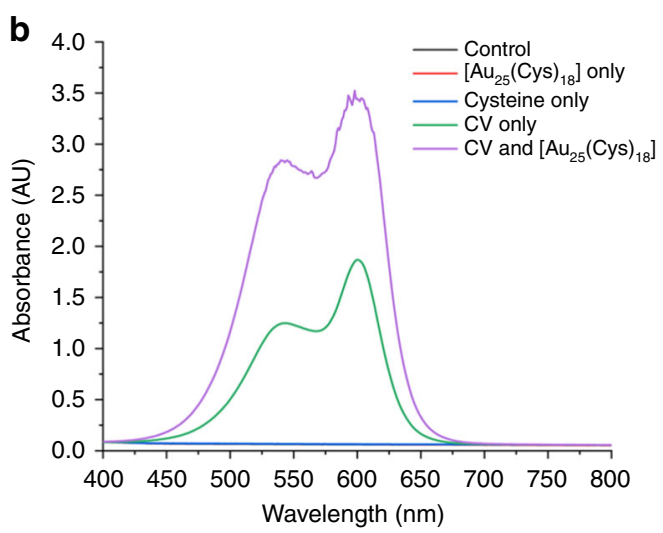

Fig. 2 Images and UV-Vis measurement of $\mathbf{2 4}$ h treated silicones. a Images of control, CV only, $\left[\mathrm{Au}_{25}(\mathrm{Cys})_{18}\right]$ only, cysteine only and CV\& $\left[\mathrm{Au}_{25}(\mathrm{Cys})_{18}\right]$. CV indicates crystal violet. $\mathbf{b} \mathrm{UV}$-Vis absorbance spectra of control, $\mathrm{CV}$ only, $\left[\mathrm{Au}_{25}(\mathrm{Cys})_{18}\right]$ only, cysteine only and $\mathrm{CV} \&\left[\mathrm{Au}_{25}(\mathrm{Cys})_{18}\right]$. and even death of patients ${ }^{38,39}$. The bactericidal activity of the polymers against S. aureus 8325-4 and E. coli ATCC 25922 was tested in the dark and under white light (average 312 lux), and the result was compared to that of a control comprised of solvent treated silicone. Twenty-five microlitres of the bacterial suspen-

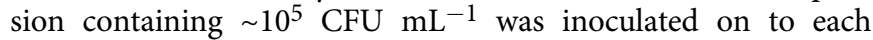
sample surface and then exposed to the white light source or maintained in a dark room at $20^{\circ} \mathrm{C}$. Supplementary Fig. 5 shows the distribution of white light intensity. The intensity ranged from 200 to 429 lux $\left(0.03\right.$ to $\left.0.06 \mathrm{~mW} \mathrm{~cm}^{-2}\right)$ and the light emission wavelength mainly ranged from 400 to $800 \mathrm{~nm}^{40}$.

Figure $3 \mathrm{a}, \mathrm{b}$ shows the bactericidal activity of the samples against $S$. aureus after $6 \mathrm{~h}$ incubation in the dark and in white light. After $6 \mathrm{~h}$ incubation in the dark, compared to the control, a reduction in the number of viable bacteria was not observed on either silicone samples containing only $\mathrm{CV}$ or $\left[\mathrm{Au}_{25}(\mathrm{Cys})_{18}\right]$ alone, whereas a statistically significant reduction in bacterial numbers was observed on the silicone samples containing cysteine only $(0.17 \log$ reduction, $T$-test: $P<0.05)$ and $C V \&$ $\left[\mathrm{Au}_{25}(\mathrm{Cys})_{18}\right] \quad(0.25 \mathrm{log}$ reduction, $T$-test: $P<0.1)$. Upon $6 \mathrm{~h}$ exposure to white light, a reduction in the number of viable bacteria was not observed on samples containing $\mathrm{CV}$ only or $\left[\mathrm{Au}_{25}(\mathrm{Cys})_{18}\right]$ only, compared to the control. Bactericidal activity of silicone containing cysteine alone was observed after $6 \mathrm{~h}$ exposure to white light, but the activity was not enhanced compared to that in the dark ( $T$-test: $P>0.1$ ). The bactericidal activity of the combined $\mathrm{CV} \&\left[\mathrm{Au}_{25}(\mathrm{Cys})_{18}\right]$ encapsulated sample was significantly enhanced after $6 \mathrm{~h}$ exposure of white light; the number of viable bacteria on the sample with $\mathrm{CV} \&\left[\mathrm{Au}_{25}(\mathrm{Cys})_{18}\right]$ fell to below the detection $\left(<10^{2} \mathrm{CFU} \mathrm{mL} \mathrm{mL}^{-1}\right)$, indicating a $>3.3$ log reduction in viable bacteria.

Figure $3 c, d$ shows the bactericidal activity of the samples against $E$. coli after $24 \mathrm{~h}$ incubation in the dark and in white light. After $24 \mathrm{~h}$ incubation in the dark, compared to the control, the 
a

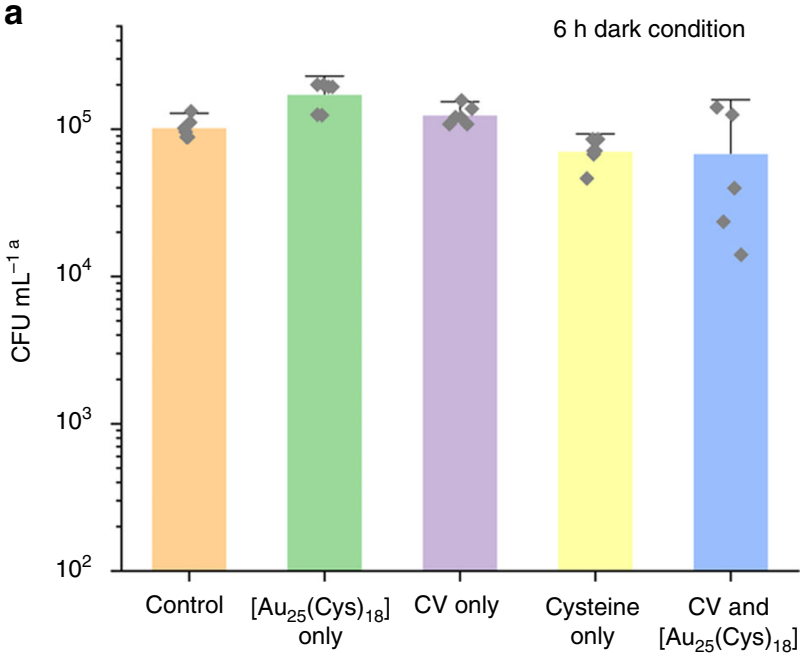

C

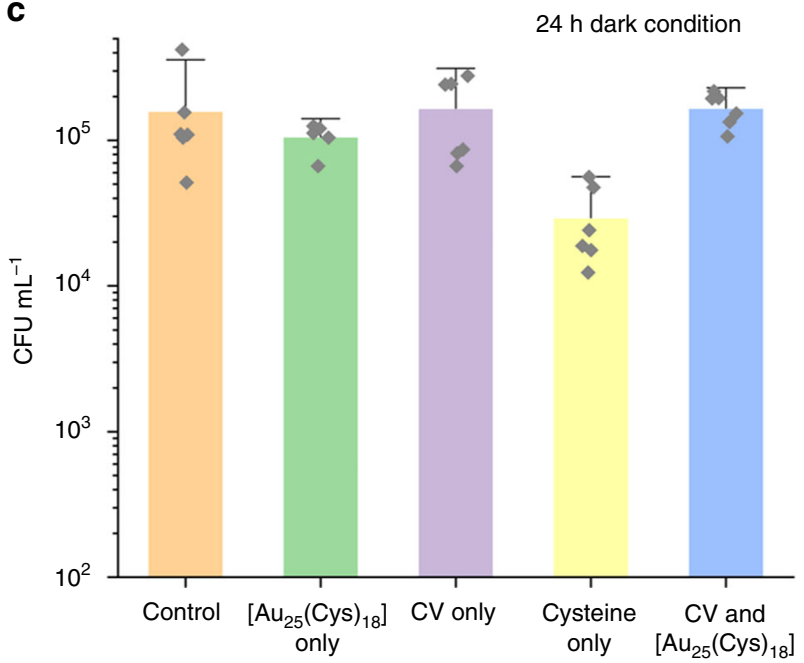

b

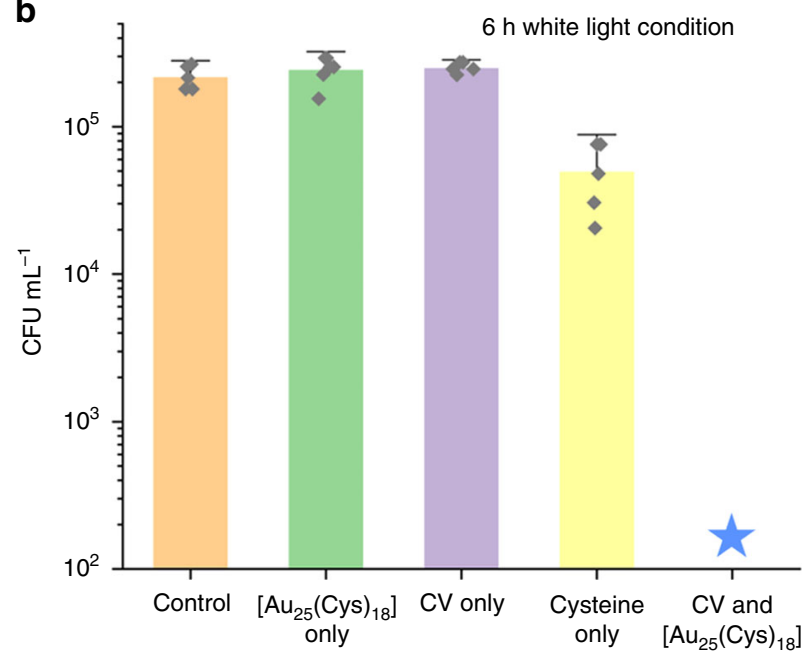

d

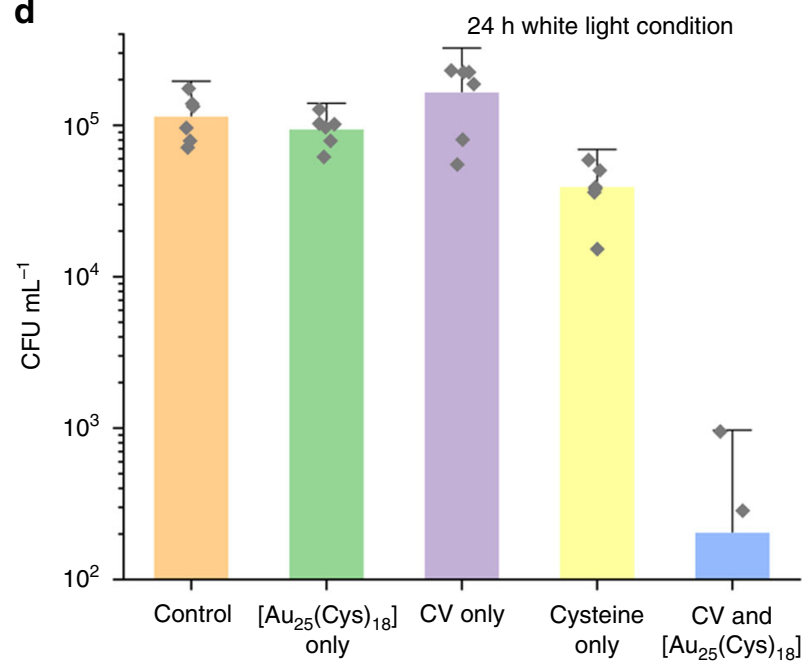

Fig. 3 Bactericidal activity of control and treated silicone samples. a Bactericidal activity of control, $\left[\mathrm{Au}_{25}(\mathrm{Cys})_{18}\right]$ only, $\mathrm{CV}$ only, $\mathrm{Cysteine}$ only and $\mathrm{CV} \&$ $\left[\mathrm{Au}_{25}(\mathrm{Cys})_{18}\right]$ against $\mathrm{S}$. aureus in dark $\left(n=6\right.$ independent samples). $\mathrm{CV}$ indicates crystal violet. $\mathbf{b}$, Bactericidal activity of control, $\left[\mathrm{Au}{ }_{25}(\mathrm{Cys})_{18}\right]$ only, $\mathrm{CV}$ only, Cysteine only and $\mathrm{CV} \&\left[\mathrm{Au}_{25}(\mathrm{Cys})_{18}\right]$ against $\mathrm{S}$. aureus in white light ( $n=6$ independent samples). c Bactericidal activity of control, $\left[\mathrm{Au} \mathbf{u}_{25}(\mathrm{Cys})_{18}\right]$ only, $\mathrm{CV}$ only, Cysteine only and $\mathrm{CV} \&\left[\mathrm{Au}_{25}(\mathrm{Cys})_{18}\right]$ against $E$. coli in the dark ( $n=6$ independent samples). d Bactericidal activity of control, $\left[A u_{25}\left(\mathrm{Cys}_{18}\right]\right.$ only, $\mathrm{CV}$ only, Cysteine only and $\mathrm{CV} \&\left[\mathrm{Au}_{25}(\mathrm{Cys})_{18}\right]$ of $E$. coli in white light ( $\mathrm{n}=6$ independent samples). Bacteria inoculated materials were exposed to white light with an intensity from 200 to 429 lux. Data presented as mean \pm SD. ${ }^{a} \mathrm{CFU} \mathrm{mL}{ }^{-1}$ indicates Colony forming unit per $\mathrm{mL}$. Blue star represents below detection limit: $<10^{2} \mathrm{CFU} \mathrm{mL}^{-1}$.

reduction in the number of viable bacteria was not statistically significant on the samples with only $\mathrm{CV}$ or $\left[\mathrm{Au}_{25}(\mathrm{Cys})_{18}\right]$ alone or $\mathrm{CV} \&\left[\mathrm{Au}_{25}(\mathrm{Cys})_{18}\right]$ (T-test: $\left.P>0.1\right)$, while a significant reduction in the numbers of viable bacteria was observed on the sample containing cysteine only $(0.7 \log$ reduction, $T$-test: $P<0.1)$. After $24 \mathrm{~h}$ exposure to white light, the polymer samples containing either $\mathrm{CV}$ or $\left[\mathrm{Au}_{25}(\mathrm{Cys})_{18}\right]$ alone did not show any bactericidal activity compared to the control, and the sample with cysteine only did not show any increase in bactericidal activity compared to that in the dark (T-test: $P>0.1$ ). However, bactericidal activity of the polymer with $\mathrm{CV} \&\left[\mathrm{Au}_{25}(\mathrm{Cys})_{18}\right]$ was significantly enhanced after $24 \mathrm{~h}$ exposure of white light compared to the control, showing a 2.8-log reduction in the number of viable bacteria ( $T$-test: $P<0.01$ ).

E. coli was more resistant than $S$. aureus requiring a longer exposure time of white light to achieve a significant reduction in the number of viable bacteria. We attribute this to differences in the cell wall, where E. coli-a Gram-negative bacterium-contains a double membrane structure compared to $S$. aureus-a Gram-positive bacterium-which contains only a single membrane barrier ${ }^{41}$. The outer membrane of Gram-negative bacterium decreases molecular penetration, and is often responsible for increased resistance to antibacterial agents ${ }^{41,42}$.

It is known that the photobactericidal mechanism of CV starts with the absorption of light, resulting in an excited singlet state which has paired electron $\operatorname{spin}^{22,28}$. This either returns to the ground state or transforms to a triplet state, which has unpaired electron $\operatorname{spin}^{22,28}$. Molecules in the triplet state undergo two photochemical reaction processes known as Type-I and -II. For Type-I, redox reactions occur with their environment resulting in ROS generation 22,28 . For Type-II, the energy is transferred to ground state molecular oxygen, resulting in the transformation from triplet oxygen $\left({ }^{3} \mathrm{O}_{2}\right)$ to singlet oxygen $\left({ }^{1} \mathrm{O}_{2}\right)^{22,28}$. These ROS and ${ }^{1} \mathrm{O}_{2}$ result in a multi-site attack on bacteria resulting in cell 

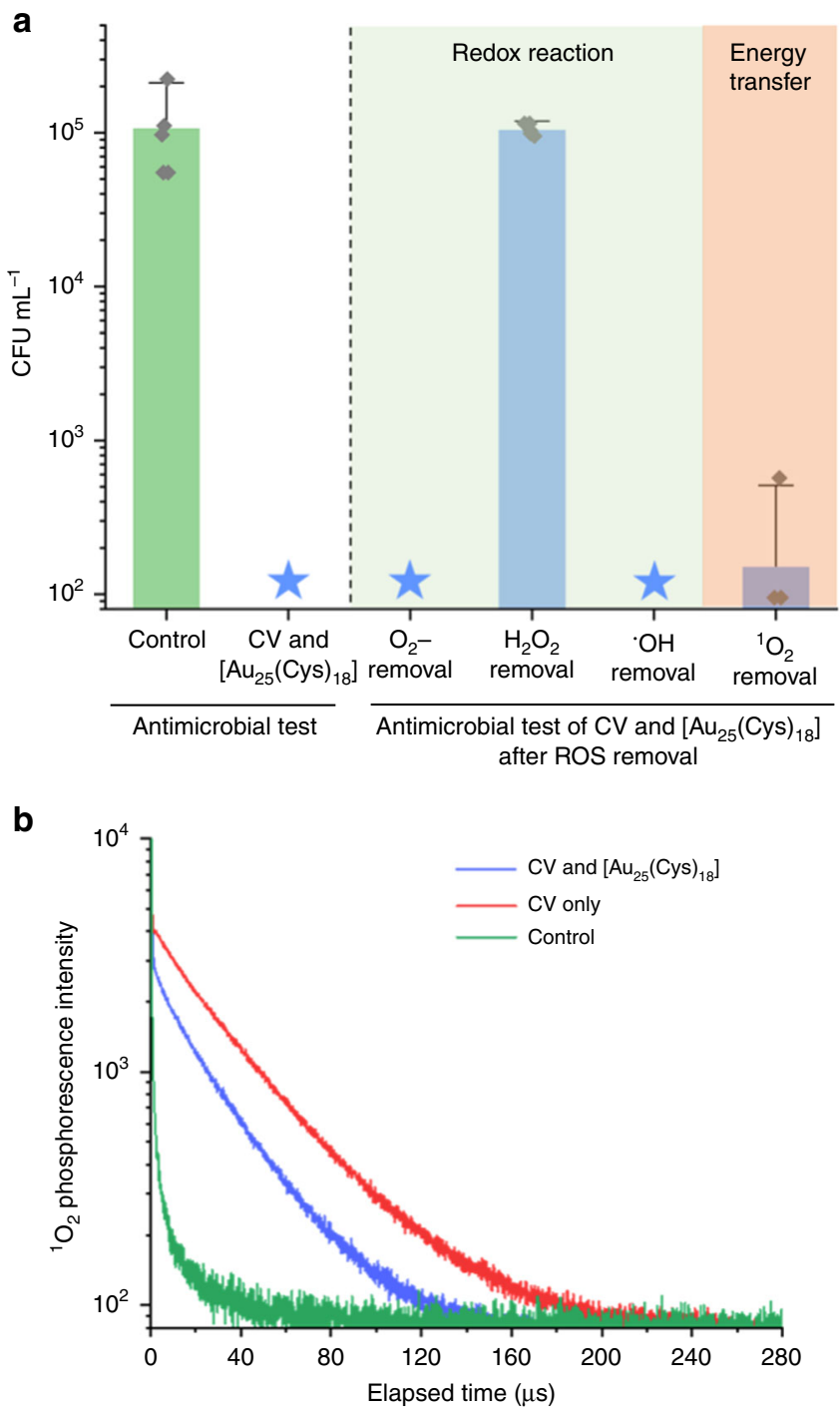

Fig. 4 Characterisation of reactive oxygen species (ROS) induced by CV only and $\mathbf{C V} \&\left[\mathbf{A u}_{\mathbf{2 5}}(\mathbf{C y s})_{\mathbf{1 8}}\right]$. a Bactericidal activity of $\mathrm{CV} \&\left[\mathrm{Au}_{25}(\mathrm{Cys})_{18}\right]$ after removal of reactive oxygen species (ROS) containing superoxide $\left(\mathrm{O}_{2}{ }^{-}\right)$, hydrogen peroxide $\left(\mathrm{H}_{2} \mathrm{O}_{2}\right)$, and singlet oxygen $\left({ }^{1} \mathrm{O}_{2}\right)$. $\mathrm{CV} \&\left[\mathrm{Au}_{25}(\mathrm{Cys})_{18}\right]$ samples were exposed to white light source with an intensity of 312 lux on average for $6 \mathrm{~h}$ ( $\mathrm{n}=6$ independent samples). CV indicates crystal violet. b Time-resolved ${ }^{1} \mathrm{O}_{2}$ phosphorescence decay on control, $\mathrm{CV}$ only, and $\left[C V \& A_{25}(C y s)_{18}\right]\left(\lambda_{E x}=532 \mathrm{~nm}, \lambda_{E m}=1270 \mathrm{~nm}\right)$. The phosphorescence decay was analysed using PicoQuant Fluofit software. Data in (a) presented as mean $\pm \mathrm{SD}$. Blue star represents below detection limit: $<10^{2} \mathrm{CFU} \mathrm{mL}-1$.

death ${ }^{26}$. The polymer containing CV only did not show any photobactericidal activity herein, upon exposure to low intensity white light. However, the addition of $\left[\mathrm{Au}_{25}(\mathrm{Cys})_{18}\right]$ to $\mathrm{CV}$ resulted in potent photobactericidal activity under identical conditions.

To determine the species responsible for the bactericidal effect observed in our $\mathrm{CV} \&\left[\mathrm{Au}_{25}(\mathrm{Cys})_{18}\right]$ system, ROS scavenger/ quencher assays and ${ }^{1} \mathrm{O}_{2}$ phosphorescence measurements were carried out. In the ROS scavenger/quencher assay, photobactericidal activity was measured in the presence of scavengers; superoxide dismutase (SOD) for superoxide radicals $\left(\mathrm{O}_{2}{ }^{-}\right)$, catalase for hydrogen peroxide $\left(\mathrm{H}_{2} \mathrm{O}_{2}\right)$, mannitol for hydroxyl radicals $(\cdot \mathrm{OH})$ and L-histidine for singlet oxygen species $\left({ }^{1} \mathrm{O}_{2}\right)^{29,43-45}$. As shown Fig. 4 a, the polymer with $\mathrm{CV} \&\left[\mathrm{Au}_{25}(\mathrm{Cys})_{18}\right]$ exhibited potent photobactericidal activity against $S$. aureus with $>3.3-\log$ reduction compared to the control after $6 \mathrm{~h}$ exposure of 312 lux white light without addition of ROS scavenger/quencher. When Lhistidine $\left({ }^{1} \mathrm{O}_{2}\right.$ quencher) was added, the photobactericidal activity of the polymer was slightly reduced, but retained strong bactericidal activity with a $2.9 \log$ reduction in the number of viable bacteria. $\mathrm{O}_{2}{ }^{-}$and $\cdot \mathrm{OH}$ scavenging by SOD and mannitol respectively did not cause any significant change in photobactericidal activity. However, the photobactericidal activity decreased from $>3.3$ to $0.02-\log$ reduction when catalase $\left(\mathrm{H}_{2} \mathrm{O}_{2}\right.$ scavenger) was added, indicating that the potent photobactericidal activity of $\mathrm{CV} \&\left[\mathrm{Au}_{25}(\mathrm{Cys})_{18}\right]$ is mainly due to $\mathrm{H}_{2} \mathrm{O}_{2}$ formation. Although the ${ }^{1} \mathrm{O}_{2}$ quencher assay showed that ${ }^{1} \mathrm{O}_{2}$ was produced by $\mathrm{CV} \&\left[\mathrm{Au}_{25}(\mathrm{Cys})_{18}\right]$ and gave some bacterial kill, it was not clear if the addition of $\left[\mathrm{Au}_{25}(\mathrm{Cys})_{18}\right]$ reinforced the Type-II pathway. Thus, to determine if Type-II was important, time-resolved nearinfrared (TRNIR) spectroscopy was employed. A laser source with a wavelength of $532 \mathrm{~nm}$ was used for light illumination on the $\mathrm{CV} \&\left[\mathrm{Au}_{25}(\mathrm{Cys})_{18}\right]$ treated polymers and ${ }^{1} \mathrm{O}_{2}$ phosphorescence was measured at a wavelength of $\sim 1270 \mathrm{~nm}^{46,47}$. Figure $4 \mathrm{~b}$ shows the ${ }^{1} \mathrm{O}_{2}$ phosphorescence decay of the control, silicone with CV only and silicone with $\mathrm{CV} \&\left[\mathrm{Au}_{25}(\mathrm{Cys})_{18}\right]$ at a wavelength of 1270 $\mathrm{nm}$. Upon laser illumination, the ${ }^{1} \mathrm{O}_{2}$ phosphorescence signal was observed on both the polymer with $\mathrm{CV}$ only and the polymer with $\mathrm{CV} \&\left[\mathrm{Au}_{25}(\mathrm{Cys})_{18}\right]$. Interestingly, the lifetime of the ${ }^{1} \mathrm{O}_{2}$ phosphorescence signal produced from the polymer with $\mathrm{CV}$ only $(\sim 33.8 \mu \mathrm{s})$ was longer than the polymer with $\mathrm{CV} \&\left[\mathrm{Au}_{25}(\mathrm{Cys})_{18}\right]$ $(\sim 25.5 \mu \mathrm{s})$. This indicates that the addition of $\left[\mathrm{Au}_{25}(\mathrm{Cys})_{18}\right]$ to $\mathrm{CV}$ appears to attenuate the Type-II pathway.

To understand the photoreaction mechanism of the polymer sample containing $\mathrm{CV} \&\left[\mathrm{Au}_{25}(\mathrm{Cys})_{18}\right]$, photocurrent measurements, steady state and time-resolved photoluminescence (PL) spectroscopies were employed. Transient photocurrent responses of $\mathrm{CV}$ only and $\mathrm{CV} \&\left[\mathrm{Au}_{25}(\mathrm{Cys})_{18}\right]$ treated polymers were measured under several on-off cycles of white light irradiation. As shown in Fig. 5a, a greater rise in photocurrent of the polymers containing $\mathrm{CV} \&\left[\mathrm{Au}_{25}(\mathrm{Cys})_{18}\right]$ compared to $\mathrm{CV}$ alone was observed, indicating a higher CV concentration and/or a higher separation efficiency of electron-hole pairs. Figure $5 \mathrm{~b}$ shows PL spectra of the samples with CV only and CV\& $\left[\mathrm{Au}_{25}(\mathrm{Cys})_{18}\right]$ from 600 to $800 \mathrm{~nm}$. The intensity of the PL spectrum is a direct measurement on recombination rate of electron-hole pair. The higher the peak intensity of the spectrum, the easier the recombination of the electron-hole pair. A PL peak of the polymer sample with CV only was observed at $\sim 675 \mathrm{~nm}$, and the PL peak of the sample with $\mathrm{CV} \&\left[\mathrm{Au}_{25}(\mathrm{Cys})_{18}\right]$ was lower than that of $\mathrm{CV}$ only indicating that the recombination rate of the photogenerated electron-hole pairs on $\mathrm{CV} \&\left[\mathrm{Au}_{25}(\mathrm{Cys})_{18}\right]$ is slower than that of $\mathrm{CV}$ only. This indicates that additional encapsulation of $\left[\mathrm{Au}_{25}(\mathrm{Cys})_{18}\right]$ into $\mathrm{CV}$-treated polymer improves the photoelectrochemical properties of the sample. Figure $5 c$ shows timeresolved PL decay of samples containing $\mathrm{CV}$ only or CV\& $\left[\mathrm{Au}_{25}(\mathrm{Cys})_{18}\right]$. The PL decay was measured at a wavelength of $650 \mathrm{~nm}$ upon excitation by a laser source with a wavelength of $574 \mathrm{~nm}$. Compared to the CV only polymer, the PL life time of the polymer sample with $\mathrm{CV} \&\left[\mathrm{Au}_{25}(\mathrm{Cys})_{18}\right]$ was shorter. This was attributed to electron transfer from $\mathrm{CV}$ to $\left[\mathrm{Au}_{25}(\mathrm{Cys})_{18}\right]^{48,49}$. It is suggested that $\left[\mathrm{Au}_{25}(\mathrm{Cys})_{18}\right]$ on the $\mathrm{CV}$-treated surface acts as an electron acceptor, resulting in better electron-hole pair separation, a reduction in recombination, and enhanced photobactericidal properties ${ }^{48,49}$.

In order to determine the band offset of the $\mathrm{CV}$ and $\left[\mathrm{Au}_{25}(\mathrm{Cys})_{18}\right]$, XPS and UV-Vis spectroscopy were used, with the results shown in Fig. 6. For XPS analysis, the adventitious $\mathrm{C}$ 1s peak at $284.8 \mathrm{eV}$ was used as a reference for charge correction. Band gap energies $\left(E_{\mathrm{G}}\right)$ of $\mathrm{CV}$ and $\left[\mathrm{Au}_{25}(\mathrm{Cys})_{18}\right]$ were 1.95 and $1.25 \mathrm{eV}$, 

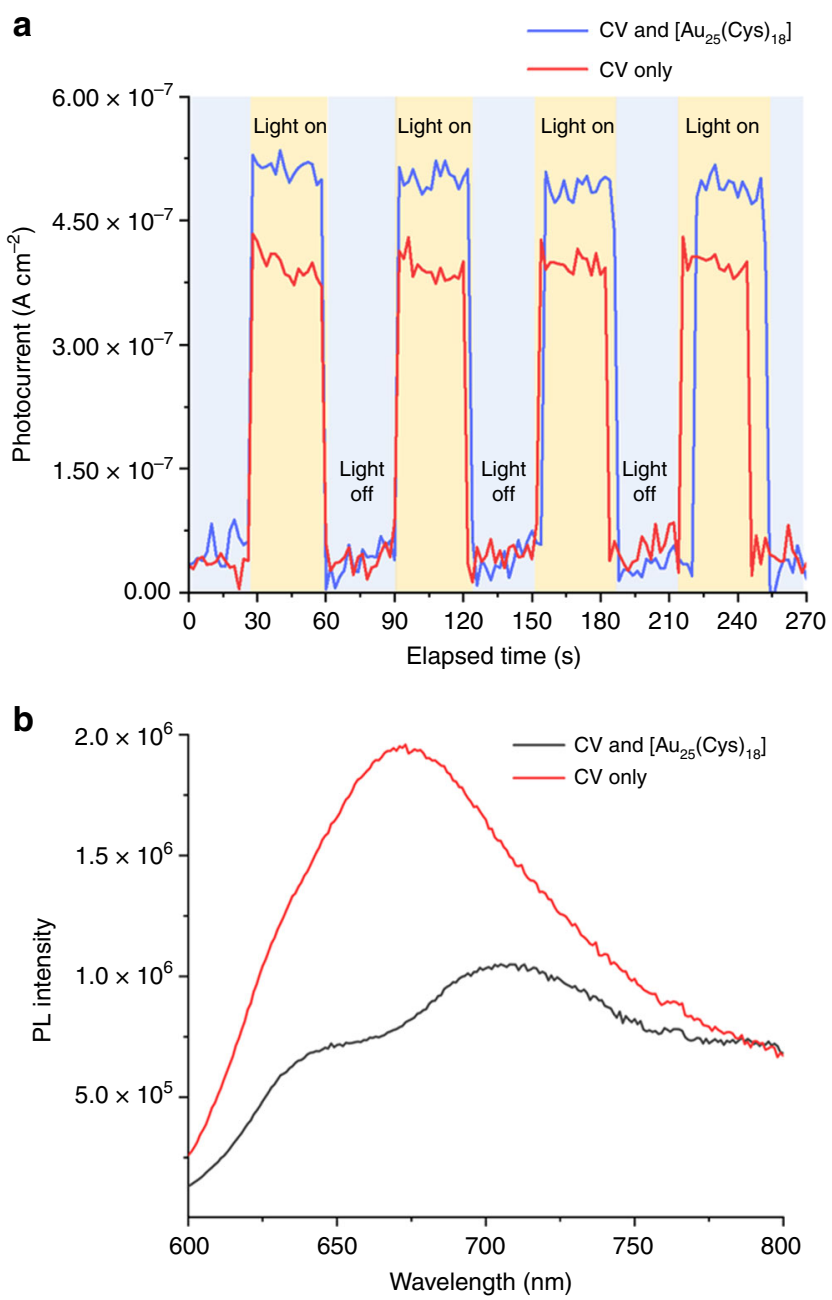

C

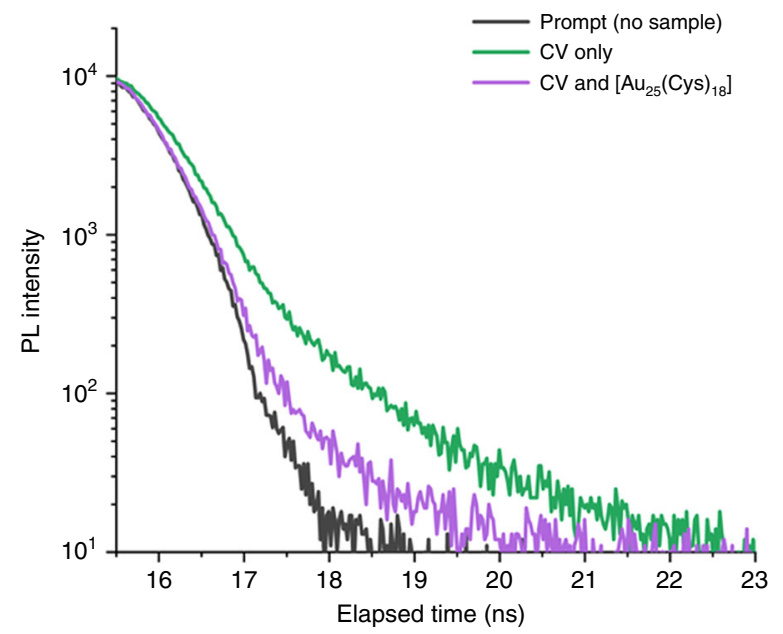

Fig. 5 Photoreaction characterisation of $\mathrm{CV}$ only and $\mathrm{CV} \&\left[\mathrm{Au}_{25}(\mathrm{Cys})_{18}\right]$. a Transient photocurrent responses for $\mathrm{CV}$ only and $\mathrm{CV} \&\left[\mathrm{Au}_{25}(\mathrm{Cys})_{18}\right]$ under white light. $\mathrm{CV}$ indicates crystal violet. b Photoluminescence (PL) spectra of $C V$ only and $\left.C V \&\left[\mathrm{Au}_{25} \text { (Cys) }\right)_{18}\right]$ in wavelength of 600 to $800 \mathrm{~nm}$ $\left(\lambda_{\mathrm{Ex}}=574 \mathrm{~nm}\right)$. c Time-resolved photoluminescence $(\mathrm{PL})$ decay of $\mathrm{CV}$ only and $\mathrm{CV} \&\left[\mathrm{Au}_{25}(\mathrm{Cys})_{18}\right]\left(\lambda_{\mathrm{Ex}}=574 \mathrm{~nm}, \lambda_{\mathrm{Em}}=650 \mathrm{~nm}\right)$.

respectively (Supplementary Fig. 6a and d) and homo band maximum energies $\left(E^{\mathrm{HBM}}\right)$ of $\mathrm{CV}$ and $\left[\mathrm{Au}_{25}(\mathrm{Cys})_{18}\right]$ were 1.6 and 1.07 $\mathrm{eV}$, respectively (Supplementary Fig. 6b, e). A difference of binding energy between $\mathrm{N}$ 1s core level (CL) and homo band was

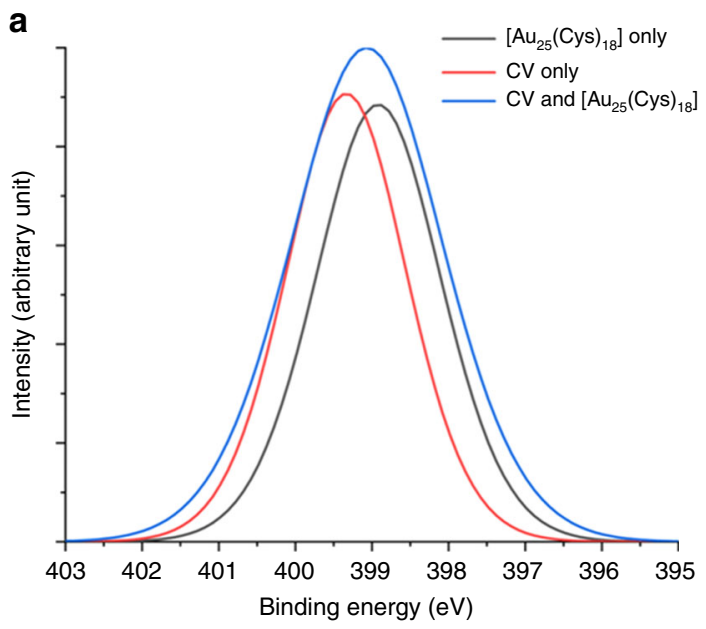

b

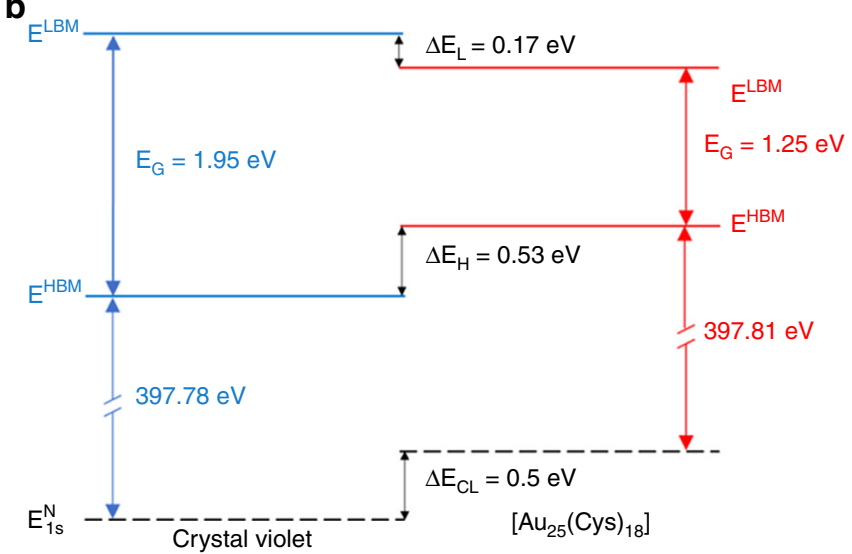

Fig. 6 Band alignment of crystal violet and $\left[\mathrm{Au}_{25}(\mathrm{Cys})_{18}\right]$ from XPS. a $\mathrm{N}$ 1s spectra taken from $\mathrm{CV}$ only, $\left[\mathrm{Au}_{25}\left(\mathrm{Cys}_{18}\right)\right]$ only and $\left.\mathrm{CV} \&\left[\mathrm{Au}_{25}(\mathrm{Cys})_{18}\right)\right]$. Experimental data shown as blue line are fitted with the peak shapes derived from phase-pure crystal violet (red line) and $\left[\mathrm{Au}_{25}(\mathrm{Cys})_{18}\right]$ (black line). b XPS band alignment between crystal violet and $\left[\mathrm{Au}_{25}(\mathrm{Cys})_{18}\right]$. CV indicates crystal violet. $E_{\mathrm{HBM}}$ is homo band maximum energy. $\Delta E_{\mathrm{H}}$ is the energy offset between $\mathrm{CV} E_{\mathrm{HBM}}$ and $\left[\mathrm{Au}_{25}(\mathrm{Cys})_{18}\right] E_{\mathrm{HBM}}$. $E_{\mathrm{LBM}}$ is lumo band maximum energy. $\Delta E_{\mathrm{L}}$ is the energy offset between $C V E_{\mathrm{LBM}}$ and $\left[\mathrm{Au}_{25}(\mathrm{Cys})_{18}\right] E_{\mathrm{LBM}} . \Delta E_{\mathrm{CL}}$ is the core level offset between the $\mathrm{N}$ 1s core levels.

investigated in $\mathrm{CV}$ only and $\left[\mathrm{Au}_{25}(\mathrm{Cys})_{18}\right]$ only samples (Supplementary Fig. $6 \mathrm{c}, \mathrm{f})$. The same functions were used to peak fit $\mathrm{N} 1 \mathrm{~s}$ peaks in $\mathrm{CV} \&\left[\mathrm{Au}_{25}(\mathrm{Cys})_{18}\right]$ to determine the binding energy (Fig. 6a). The $\mathrm{N}$ 1s CL environments can be considered equivalent in these materials, and can therefore be used as a reference point to determine the band alignment. As shown in Fig. 6b, the difference of binding energy between $\mathrm{N} 1 \mathrm{CL}$ and $E^{\mathrm{HBM}}$ was $397.78 \mathrm{eV}$ for $\mathrm{CV}$ and $397.81 \mathrm{eV}$ for $\left[\mathrm{Au}_{25}(\mathrm{Cys})_{18}\right]$. The $E^{\mathrm{HBM}}$ of $\left[\mathrm{Au}_{25}(\mathrm{Cys})_{18}\right]$ was $0.53 \mathrm{eV}$ higher than that of $\mathrm{CV}$ while the lumo band maximum energy $\left(E^{\mathrm{LBM}}\right)$ of $\mathrm{CV}$ was $0.17 \mathrm{eV}$ higher than that of $\left[\mathrm{Au}_{25}(\mathrm{Cys})_{18}\right]$, indicating the formation of a straddling (type I) band alignment at the interface between $\mathrm{CV}$ and $\left[\mathrm{Au}_{25}(\mathrm{Cys})_{18}\right]^{50,51}$. This alignment suggests, that upon white light illumination, photogenerated electrons can flow from $\mathrm{CV}$ to $\left[\mathrm{Au}_{25}(\mathrm{Cys})_{18}\right]$, resulting in electron accumulation in $\left[\mathrm{Au}_{25}(\mathrm{Cys})_{18}\right]$; in agreement with time-resolved PL measurements (Fig. 5c).

For the widespread use of photobactericidal coatings in hospitals and other indoor facilities, the light source should be carefully considered. Firstly, the light source should not produce 


\begin{tabular}{|c|c|}
\hline Location & Illumination (lux) \\
\hline Reception and enquiry desk & $300-500$ \\
\hline Desk in nurse station & 300 \\
\hline \multicolumn{2}{|l|}{ Bedded (ward) area } \\
\hline Patient reading & 300 \\
\hline General nursing care & 300 \\
\hline Examination and treatment & 1000 \\
\hline \multicolumn{2}{|l|}{ Operating theatre } \\
\hline Working plane & $500-1000$ \\
\hline Operating table & $15,000-30,000$ \\
\hline \multicolumn{2}{|c|}{ Accident and Emergency (A\&E) unit } \\
\hline Working plane & $500-1000$ \\
\hline Couch & $15,000-90,000$ \\
\hline Dentistry unit & $500-1000$ \\
\hline Maternity unit & $300-1000$ \\
\hline Sterilising and disinfection unit & 300 \\
\hline Diagnostic equipment room & 500 \\
\hline
\end{tabular}

The guideline was sourced from lighting guide 2 - hospitals and health care buildings ${ }^{61}$.

an adverse effect on hospital staff and patients. Secondly, because light sources typically range from 300 (corridors, rooms) to 90,000 lux (operating theatre) in hospitals and healthcare facilities (Table 1), potent photobactericidal activity should be present at various lighting conditions. Titanium dioxide $\left(\mathrm{TiO}_{2}\right)$ and zinc oxide $(\mathrm{ZnO})$ nanoparticles are the most extensively studied photocatalysts, and they exhibit a broad photobactericidal spectrum $^{52-54}$. However, their bactericidal activity is negligible under white light sources, which are commonly used in healthcare facilities, because $\mathrm{TiO}_{2}$ and $\mathrm{ZnO}$ nanoparticles are $\mathrm{UV}$-active photocatalysts, and the portion of UV light present in indoor lighting is typically extremely low ${ }^{52}$. To produce enhanced indoor photocatalysts, $\mathrm{TiO}_{2}$ based nanocomposites using $\mathrm{Ag}$ NPs and $\mathrm{Au}$ NPs, carbon nanotube (CNT), and graphene oxide (GO) etc have been studied ${ }^{53-55}$. Although some of the composites exhibited bactericidal activity under a white light source, such studies typically employed an intense light source of $>1300$ lux $(0.2 \mathrm{~mW}$ $\mathrm{cm}^{-2}$ ) indicating lack of feasibility for use in healthcare facilities (Table 1$)^{2,53-58}$. In recent years, it was reported that TBO, CV, and $\mathrm{MB}$ treated polymer surfaces exhibit photobactericidal activity and the addition of $2 \mathrm{~nm} \mathrm{Au} \mathrm{NPs}$ or $3 \mathrm{~nm} \mathrm{ZnO} \mathrm{NPs}$ within the treated surface results in enhanced photobactericidal activity 24,26,29,59. However, intense white light of $>1000$ lux $\left(>0.15 \mathrm{~mW} \mathrm{~cm}^{-2}\right)$ or a $\sim 600 \mathrm{~nm}$ laser source had to be employed to achieve potent bacterial kill, indicating that such polymers can only be used in healthcare environments with extremely bright lighting, such as operating theatres and A\&E examination units (Table 1) $24,26,29,59,60$. Our study showed that the addition of $\left[\mathrm{Au}_{25}(\mathrm{Cys})_{18}\right]$ into a $\mathrm{CV}$ impregnated polymer significantly enhances its photobactericidal activity, showing potency under low intensity white light ranging from 200 to 429 lux (0.03 to $0.06 \mathrm{~mW} \mathrm{~cm}^{-2}$ ), which is $>3$ times lower light levels than previous studies $24,26,29,53-55,59,60$. Moreover, this dye-cluster combination can be applied to a wide range of devices based on polymer such as endotracheal tubing, keyboard cover, catheter, screen cover, tablet and phone covers.

The polymer encapsulated with $\mathrm{CV} \&\left[\mathrm{Au}_{25}(\mathrm{Cys})_{18}\right]$ displayed potent bactericidal activity against $S$. aureus and $E$. coli, which are both associated with hospital acquired infections (HAIs). An illumination with a white light source (312 lux) of similar intensity to that commonly found in healthcare facilities resulted in a significant enhancement of the bactericidal activity of the polymer with $>3.3$ and $2.8 \log$ reductions for $S$. aureus and E. coli respectively after 6 and $24 \mathrm{~h}$ of exposure to white light. Our studies of the photobactericidal mechanism showed that upon white light illumination, photogenerated electrons in CV likely flow into $\left[\mathrm{Au}_{25}\right.$ (Cys) $\left.{ }_{18}\right]$ (Fig. 6). This indicated that redox reaction was induced from $\left[\mathrm{Au}_{25}(\mathrm{Cys})_{18}\right]$. Chemical scavenger and TRNIR spectroscopy studies showed that the Type-II pathway for forming ${ }^{1} \mathrm{O}_{2}$ was suppressed in the $\mathrm{CV} \&\left[\mathrm{Au}_{25}(\mathrm{Cys})_{18}\right]$ system, and that the redox reaction to form $\mathrm{H}_{2} \mathrm{O}_{2}$ was promoted. The photobactericidal polymer containing $\mathrm{CV} \&\left[\mathrm{Au}_{25}(\mathrm{Cys})_{18}\right]$, which we report herein is a promising candidate for use in healthcare environments to prevent the spread of HAIs because its potent photobactericidal activity at ambient light levels (Table 1).

\section{Methods}

Synthesis of gold nanocluster $\left(\left[\mathbf{A} \mathbf{u}_{\mathbf{2 5}}(\mathbf{C y s})_{\mathbf{1 8}}\right]\right)$. Supplementary Fig. 1 shows a set-up of microfluidic segmented flow system to synthesize $\left[\mathrm{Au}_{25}(\mathrm{Cys})_{18}\right]$. It consists of a tube-in-tube membrane contactor, and a coil flow inverter reactor. The tube-in-tube contactor consists of polytetrafluoroethylene (PTFE) tubing (inner diameter: $3.2 \mathrm{~mm}$, VICI Jour), and Teflon AF-2400 tubing (inner diameter: $0.8 \mathrm{~mm}$, Cambridge Reactor Design Ltd) located in PTFE tubing. CO (BOC) was dissolved into heptane in the tube-in-tube contactor and then the mixture was saturated under $500 \mathrm{kPa} .21 .8 \mathrm{mg}$ of cysteine and $3 \mathrm{~mL}$ of tetrachloauric acid stock solution (59.5 mM, Sigma-Aldrich) were mixed in de-ionized (DI) water to form $40 \mathrm{~mL}$ of the thiolate-Au (I) complex solution $(3 \mathrm{mM})$, the $\mathrm{pH}$ of the solution was maintained at 11.6 using sodium hydroxide $(\mathrm{NaOH}, 2 \mathrm{~N}$, Sigma-Aldrich). The complex was mixed with CO-saturated heptane and then it passed through the coiled flow inverter at $80^{\circ} \mathrm{C}$. The coiled flow inverter reactor consists of 100 coils of fluorinated ethylene propylene (FEP) tubing (inner diameter: $1 \mathrm{~mm}$, VICI Jour). The diameter of the coil was about $1 \mathrm{~cm}$ and $90^{\circ}$ bend was applied at every five coils. After the reactor, the solution was mixed with nitrogen gas in the collection flask. Through the microfluidic segmented flow system, $\left[\mathrm{Au}_{25}(\mathrm{Cys})_{18}\right]$ clusters were synthesized within about 3 minutes of residence time. $\left[\mathrm{Au}_{25}(\mathrm{Cys})_{18}\right]$ solution was placed at room temperature overnight. After that, an organic layer which is formed by heptane on the top of the solution was removed.

TEM and UV-Vis absorbance spectroscopy. In order to determine the size and morphology of the cluster, transmission electron microscopy (TEM, JEOL 2100, JEOL Ltd.) was used. A droplet of the cluster solution was inoculated on the TEM grid and dried in air. The TEM image of $\left[\mathrm{Au}_{25}(\mathrm{Cys})_{18}\right]$ was taken at an accelerating voltage of $120 \mathrm{kV}$. UV-Vis absorption spectrum of [ $\mathrm{Au}_{25}(\mathrm{Cys})_{18}$ ] solution was measured using a UV-Vis spectrometer with mini halogen light source (USB 2000 + UV-Vis-ES, Ocean Optic Inc.).

Electrospray ionization-mass spectrometry. To characterise $\left[\mathrm{Au}_{25}(\mathrm{Cys})_{18}\right]$, the dried nanoclusters were mixed with DI water containg $0.01 \mu \mathrm{M}$ cesium acetate, and then the solution was infused into an electrospray ionization-mass spectrometer (ESI-MS, Q-TOF 6510, Agilent Technology) at a flow rate of $20 \mu \mathrm{L} \mathrm{min}{ }^{-1}$. The electrospray ionization (ESI) was operated in negative mode, and heated nitrogen (the drying gas) was supplied into the spectrometer at a flow rate of $5 \mathrm{~L} \mathrm{~min}^{-1}$. The negatively charged ions were analysed by mass spectrometer (MS).

Concentration of gold nanocluster $\left(\left[\mathrm{Au}_{\mathbf{2 5}}(\mathrm{Cys})_{18}\right]\right)$. The concentration of synthesized $\left[\mathrm{Au}_{25}(\mathrm{Cys})_{18}\right]$ was calculated by Eq. (1):

$$
\mathrm{C}=\frac{\mathrm{A}}{\varepsilon \ell}
$$

where $\mathrm{C}$ and $\mathrm{A}$ indicate the concentration $(\mathrm{mM})$ of $\left[\mathrm{Au}_{25}(\mathrm{Cys})_{18}\right]$ clusters and the absorbance of the cluster solution at $670 \mathrm{~nm}$, respectively, $\varepsilon$ and $\ell$ represent molar absorption coefficient at $670 \mathrm{~nm}$ and path length through the sample, respectively.

Preparation of photobactericidal surface. In a mixture of acetone $(140 \mathrm{~mL})$ $\left[\mathrm{Au}_{25}(\mathrm{Cys})_{18}\right]$ clusters $(28 \mathrm{~mL})$, distilled (DI) water $(112 \mathrm{~mL})$ or acetone $(140 \mathrm{~mL})$ and DI water $(140 \mathrm{~mL}), 224 \mathrm{mg}$ of crystal violet (CV, Sigma-Aldrich) was dissolved at a concentration of $800 \mathrm{ppm}$. Silicone sheet $(4.5 \mathrm{~cm} \times 7.0 \mathrm{~cm})$ was immersed in $280 \mathrm{~mL}$ of was dissolved for $24 \mathrm{~h}$. The sheet was collected from the solution, washed by DI water two times to remove unbound materials, and then air dried for $24 \mathrm{~h}$ in a dark room. After that, the sheet was cut into small pieces $(1.5 \mathrm{~cm} \times 1.5 \mathrm{~cm})$.

Characterisation of photobactericidal surface. UV-Vis absorbance spectra of the control, and treated silicone samples were measured by UV-Vis spectrometer (Lambda 25, PerkinElmer Inc.), and the absorbance was measured in a range of $400-1000 \mathrm{~nm}$.

To determine the CV diffusion in silicone, the polymer was immersed in CV solution for $0.5,1,5$ and $24 \mathrm{~h}$, and it was sliced into $30 \mu \mathrm{m}$ thickness using a microtome. The sliced sample was mounted onto a glass slide and then its side section 
was imaged using fluorescence microscopy (Olympus BX63, Tokyo, Japan) with TRITC filter (excitation/emission wavelengths $545 \mathrm{~nm} / 620 \mathrm{~nm}$ ). The samples were also photographed by optical microscopy, and then the image was analysed using ImageJ (http://imagej.nih.gov/ij/) to obtain the cross-sectional intensity profiles.

X-ray photoelectron spectroscopy (XPS). XPS depth profile was employed to determine the existence of $\left[\mathrm{Au}_{25}(\mathrm{Cys})_{18}\right]$ within the treated polymer matrix and at the polymer surface. The binding energies of Au atom were determined after 0, 200 and $400 \mathrm{~s}$ of sputtering.

X-ray fluorescence (XRF) analysis. XRF analysis was employed to determine a change of $\mathrm{CV}$ concentration after additional encapsulation of $\left[\mathrm{Au}_{25}(\mathrm{Cys})_{18}\right]$ into $\mathrm{CV}$-treated polymer. The treated polymer $(1.5 \mathrm{~cm} \times 1.5 \mathrm{~cm})$ was placed into pot with colourless substrate and then it was located into XRF spectrometer (15watt Epsilon 4, Malvern Panalytical Ltd, UK).

Bactericidal test. The bactericidal activity of control and the treated polymers were tested against Staphylococcus aureus 8325-4 and Escherichia coli ATCC 25922 under dark and white light conditions. S. aureus and E. coli were stored in brain heart infusion broth (BHI, Oxoid Ltd., Hampshire, England, UK) with 20\% glycerol at $-70^{\circ} \mathrm{C}$, respectively and then they were propagated on either mannitol salt agar (Oxoid Ltd.) or MacConkey agar (Oxoid Ltd.) at $37^{\circ} \mathrm{C}$, respectively. One of the bacterial colonies grown on the agar was inoculated into BHI broth and cultured at $37^{\circ} \mathrm{C}$ with $200 \mathrm{rpm}$ shaking. After $18 \mathrm{~h}$ of culture, the bacteria were harvested through centrifugation $\left(20^{\circ} \mathrm{C}, 2795 \times g\right.$ for $\left.5 \mathrm{~min}\right)$, washed using $10 \mathrm{~mL}$ of PBS to remove BHI broth and then centrifuged to get the bacteria resuspended into $10 \mathrm{~mL}$ of PBS. The washed bacterial suspension was 10000 -fold diluted to obtain $\sim 10^{5} \mathrm{CFU} \mathrm{mL}{ }^{-1}$. As shown in Supplementary Fig. 7, $25 \mu \mathrm{L}$ of the bacterial suspension was inoculated onto the control and the treated sample surface and then the samples were located in a colourless petri dish containing wet filter paper to obtain constant humidity. After that, the samples were exposed to white light (Osram L58W/865Lumilux, Munich, German) while a same set of samples was kept in a dark room, and then the samples were placed in $450 \mu \mathrm{L}$ of PBS and vortexed for $1 \mathrm{~min}$ to wash out bacteria from the sample into the PBS. After a serial dilution, S. aureus and E. coli suspensions (each $100 \mu \mathrm{L}$ ) were plated onto mannitol salt agar and MaConkey agar, respectively and cultured at $37^{\circ} \mathrm{C}$ for $24 \mathrm{~h}$. The bacterial colonies which were grown in the agar were counted. Each experiment contained two technical replicates and the experiment was reproduced three times.

\section{Detection of superoxide radical, hydrogen peroxide, hydroxyl radical and} singlet oxygen species. S. aureus $8425-4$ and catalase (Sigma-Aldrich), L-histidine (Sigma-Aldrich), mannitol (Sigma-Aldrich) and superoxide dismutase (SOD, Sigma-Aldrich) which are scavengers and quenchers of ROS were used. Catalase was used at a concentration of 6-14 unit $\mathrm{mL}^{-1}$ in bacterial solution to remove hydrogen peroxide $\left(\mathrm{H}_{2} \mathrm{O}_{2}\right)$. SOD was used at a concentration of $\sim 20$ unit mL $\mathrm{mL}^{-1}$ in bacterial suspension to remove superoxide $\left(\mathrm{O}_{2}{ }^{-}\right)$radicals. Mannitol was used at a concentration of $82 \mathrm{mM}$ in bacterial solution to eliminate hydroxyl radicals $\left({ }^{\circ} \mathrm{OH}\right)$. L-histidine was used at a concentration of $2 \mathrm{mM}$ in bacterial solution as singlet oxygen $\left({ }^{1} \mathrm{O}_{2}\right)$ quencher. The catalase and SOD scavengers which are enzyme act extracellularly since they are large molecules. Thus, the catalase intercepts the hydrogen peroxide coming from the surface. Twenty-five microlitres of the bacterial suspension containing ROS scavenger or quencher was inoculated onto antimicrobial sample, the samples were located on to a colourless petri dish containing wet filter paper, and then they were was exposed to white light for $6 \mathrm{~h}$. After that, samples were located in $450 \mu \mathrm{L}$ of PBS and vortexed for $1 \mathrm{~min}$ to wash out bacteria from the sample to PBS. After a serial dilution, $100 \mu \mathrm{L}$ of bacterial suspension was plated onto mannitol salt agar and cultured at $37^{\circ} \mathrm{C}$ for $24 \mathrm{~h}$. The bacterial colonies which were grown in the agar were counted. Each experiment contained two technical replicates and the experiment was reproduced three times.

Detection of time-resolved singlet oxygen phosphorescence. In order to detect singlet oxygen $\left({ }^{1} \mathrm{O}_{2}\right)$ phosphorescence, a near-infrared sensitive thermoelectrically cooled photomultiplier was employed. The silicone sample was placed onto a slide glass and irradiated by Nd:YAG laser operating at $532 \mathrm{~nm}$. A PC-mounted multiscaler board with pre-amplifier (MSA-300, Becker-Hickl) was used as the photon counting system to measure singlet oxygen phosphorescence at a wavelength of $\sim 1270 \mathrm{~nm}$. After the measurement, the data was analysed using FluoFit software (PicoQuant GmbH).

Photoelectrochemical measurement and PL spectroscopy. Photocurrent measurements were performed using Metrohm Autolab (PGSTAT302N, Utrecht, Netherlands) with a three-electrode system with an external source of white light. $\mathrm{Ag} / \mathrm{AgCl}$ reference electrode, and platinum sheet as a counter electrode. The photobactericidal polymer (CV only and $\left.\mathrm{CV} \&\left[\mathrm{Au}_{25}\left(\mathrm{Cys}_{18}\right)\right]\right)$ served as the working electrode. The electrolyte used in the system was $0.1 \mathrm{M} \mathrm{Na}_{2} \mathrm{SO}_{4}$.

PL spectra of samples were measured in a wavelength of 600 to $800 \mathrm{~nm}$ using steady state PL spectrometer (FluoroMax, Horiba Scientific, Kyoto, Japan). The excitation wavelength was $\sim 574 \mathrm{~nm}$.
Time-resolved PL spectroscopy. Time-resolved PL spectroscopy, for timescales up to $100 \mathrm{~ns}(\sim 24.4 \mathrm{ps}$ resolution), was performed using a time-correlated single photo counting (TCSPC) apparatus (DeltaFlex, Horiba Scientific). Pulsed 574 $\mathrm{nm}$ excitation ( $1 \mathrm{Mz}$ repetition rate, $<1.6 \mathrm{~ns}$ pulse width) was generated by a laser diode (NanoLED-570), and the fluorescence was detected at wavelengths at 650 $\mathrm{nm}$ (Picosecond Photon Detection Module, PPD-900, Horiba Scientific, Kyoto, Japan).

Zeta potential measurement. Zeta potential of the $\left[\mathrm{Au}_{25}(\mathrm{Cys})_{18}\right]$ in the mixture of water and acetone were measured by Delsa zeta potential anlyzer (DelsaMaxPro, Beckman Coulter) with the available flow cell system in batch mode at $22^{\circ} \mathrm{C}$.

Measurement of band offset. XPS was employed to determine the band offset of $\mathrm{CV}$ and $\left[\mathrm{Au}_{25}(\mathrm{Cys})_{18}\right]$. The energy difference between a $\mathrm{CL}$ and homo band maximum (HBM) for individual materials was measured and then the difference between CLs of CV and $\left[\mathrm{Au}_{25}(\mathrm{Cys})_{18}\right]$ was measured. Subsequently, the band alignment and energy offset were determined by Eq. (2):

$$
\Delta E_{\mathrm{HBM}}=\left(E_{\mathrm{CL}}^{\text {Au cluster }}-E_{\mathrm{HBM}}^{\text {Au cluster }}\right)-\left(E_{\mathrm{CL}}^{\mathrm{CV}}-E_{\mathrm{HBM}}^{\mathrm{CV}}\right)-\Delta E_{\mathrm{CL}}
$$

where $E_{\mathrm{CL}}^{\mathrm{Aucluster}}$ and $E_{\mathrm{CL}}^{\mathrm{CV}}$ are the energy of $\left[\mathrm{Au}_{25}(\mathrm{Cys})_{18}\right]$ and $\mathrm{CV}$ core levels, respectively and $E_{\mathrm{HBM}}^{\mathrm{Au} \text { cluster }}$ and $E_{\mathrm{HBM}}^{\mathrm{CV}}$ are the energy of $\left[\mathrm{Au}_{25}(\mathrm{Cys})_{18}\right]$ and $\mathrm{CV} \mathrm{HBMs}$, respectively. $\Delta E_{\mathrm{CL}}$ is $E_{\mathrm{CL}}^{\mathrm{Au} \text { cluster }}-E_{\mathrm{CL}}^{\mathrm{CV}}$ and $\Delta E_{\mathrm{HBM}}$ is $E_{\mathrm{HBM}}^{\mathrm{Au} \text { cluster }}-E_{\mathrm{HBM}}^{\mathrm{CV}}$. Additionally, to determine the peaks' position of XPS spectra precisely, Shirley background and Gaussian-Lorentzian profiles were used.

Statistical analysis. Statistical T-test of results was calculated by Excel software (Microsoft corporation, NM, USA)

Reporting summary. Further information on research design is available in the Nature Research Reporting Summary linked to this article.

\section{Data availability}

The data presented in this manuscript are available from the corresponding author upon reasonable request. The source data underlying Figs. 1a, c, d, 2b, 4a, b, 5a-c, 6a, and Supplementary Figs. 2, 3b, c, 6a-f are provided as a Source Data file.

Received: 21 March 2019; Accepted: 11 February 2020;

Published online: 05 March 2020

\section{References}

1. Turner, N. A. et al. Methicillin-resistant Staphylococcus aureus: an overview of basic and clinical research. Nat. Rev. Microbiol. 17, 203-218 (2019).

2. Lee, J. Y. H. et al. Global spread of three multidrug-resistant lineages of Staphylococcus epidermidis. Nat. Microbiol. 3, 1175-1185 (2018).

3. Willyard, C. The drug-resistant bacteria that pose the greatest health threats. Nature 543, 15 (2017)

4. Ingle, D. J., Levine, M. M., Kotloff, K. L., Holt, K. E. \& Robins-Browne, R. M Dynamics of antimicrobial resistance in intestinal Escherichia coli from children in community settings in South Asia and sub-Saharan Africa. Nat. Microbiol. 3, 1063-1073 (2018).

5. Centers for disease control and prevention (CDC), National and state healthcare associated infections progress report, https://www.cdc.gov/HAI/ pdfs/progress-report/hai-progress-report-2015.pdf (2015).

6. House of commons, Committe of public account, Reducing healthcare associated infection in hospitals in England: Fifty-second report of session 2008-09, http://www.publications.parliament.uk/pa/cm200809/cmselect/ cmpubacc/812/812.pdf (2009).

7. Pidot, S. J. et al. Increasing tolerance of hospital Enterococcus faecium to handwash alcohols. Sci. Transl. Med. 10, eaar6115 (2018).

8. Otter, J. A., Yezli, S., Salkeld, J. A. \& French, G. L. Evidence that contaminated surfaces contribute to the transmission of hospital pathogens and an overview of strategies to address contaminated surfaces in hospital settings. Am. J. Infect. Control 41, S6-S11 (2013).

9. Boyce, J. M., Potter-Bynoe, G., Chenevert, C. \& King, T. Environmental contamination due to methicillin-resistant Staphylococcus aureus: possible infection control implications. Infect. Control Hosp. Epidemiol. 18, 622-627 (1997).

10. Huslage, K., Rutala, W. A., Sickbert-Bennett, E. \& Weber, D. J. A quantitative approach to defining "high-touch" surfaces in hospitals. Infect. Control Hosp. Epidemiol. 31, 850-853 (2010).

11. Kramer, A., Schwebke, I. \& Kampf, G. How long do nosocomial pathogens persist on inanimate surfaces? A systematic review. BMC Infect. Dis. 6, 130 (2006). 
12. Yezli, S. \& Otter, J. A. Minimum infective dose of the major human respiratory and enteric viruses transmitted through food and the environment. Food Environ. Virol. 3, 1-30 (2011).

13. Hayden, M. K., Blom, D. W., Lyle, E. A., Moore, C. G. \& Weinstein, R. A. Risk of hand or glove contamination after contact with patients colonized with vancomycin-resistant enterococcus or the colonized patients' environment. Infect. Control Hosp. Epidemiol. 29, 149-154 (2008).

14. Byers, K. E. et al. Disinfection of hospital rooms contaminated with vancomycin-resistant Enterococcus faecium. Infect. Control Hosp. Epidemiol 19, 261-264 (1998).

15. Manian, F. A. et al. Isolation of Acinetobacter baumannii complex and methicillin-resistant Staphylococcus aureus from hospital rooms following terminal cleaning and disinfection: can we do better? Infect. Control Hosp. Epidemiol. 32, 667-672 (2011).

16. Morter, S. et al. Norovirus in the hospital setting: virus introduction and spread within the hospital environment. J. Hosp. Infect. 77, 106-112 (2011)

17. Wood, S., Metcalf, D., Devine, D. \& Robinson, C. Erythrosine is a potential photosensitizer for the photodynamic therapy of oral plaque biofilms. $J$. Antimicrob. Chemother. 57, 680-684 (2006).

18. Docampo, R., Moreno, S., Muniz, R., Cruz, F. \& Mason, R. Light-enhanced free radical formation and trypanocidal action of gentian violet (crystal violet). Science 220, 1292-1295 (1983).

19. Henderson, B. W. \& Dougherty, T. J. How does photodynamic therapy work? Photochem. Photobiol. 55, 145-157 (1992).

20. Hamblin, M. R. \& Hasan, T. Photodynamic therapy: a new antimicrobial approach to infectious disease? Photochem. Photobiol. Sci. 3, 436-450 (2004).

21. Vatansever, F. et al. Antimicrobial strategies centered around reactive oxygen species-bactericidal antibiotics, photodynamic therapy, and beyond. FEMS Microbiol. Rev. 37, 955-989 (2013).

22. Wainwright, M. Photodynamic antimicrobial chemotherapy (PACT). J. Antimicrob. Chemother. 42, 13-28 (1998).

23. Perni, S. et al. Toluidine blue-containing polymers exhibit potent bactericidal activity when irradiated with red laser light. J. Mater. Chem. 19, 2715 (2009).

24. Hwang, G. B. et al. White light-activated antimicrobial surfaces: effect of nanoparticles type on activity. J. Mater. Chem. B 4, 2199-2207 (2016).

25. Piccirillo, C. et al. Antimicrobial activity of methylene blue and toluidine blue O covalently bound to a modified silicone polymer surface. J. Mater. Chem. 19, 6167 (2009).

26. Noimark, S., Allan, E. \& Parkin, I. P. Light-activated antimicrobial surfaces with enhanced efficacy induced by a dark-activated mechanism. Chem. Sci. 5 , 2216-2223 (2014).

27. Ozkan, E., Allan, E. \& Parkin, I. P. The antibacterial properties of lightactivated polydimethylsiloxane containing crystal violet. RSC Adv. 4, 51711-51715 (2014).

28. Hwang, G. B., Allan, E. \& Parkin, I. P. White light-activated antimicrobial paint using crystal violet. ACS Appl. Mater. Interfaces 8, 15033-15039 (2016).

29. Sehmi, S. K. et al. Lethal photosensitisation of Staphylococcus aureus and Escherichia coli using crystal violet and zinc oxide-encapsulated polyurethane. J. Mater. Chem. B 3, 6490-6500 (2015).

30. Noimark, S. et al. Incorporation of methylene blue and nanogold into polyvinyl chloride catheters; a new approach for light-activated disinfection of surfaces. J. Mater. Chem. 22, 15388 (2012).

31. Zhu, M., Aikens, C. M., Hollander, F. J., Schatz, G. C. \& Jin, R. Correlating the crystal structure of a thiol-protected Au25 cluster and optical properties. J. Am. Chem. Soc. 130, 5883-5885 (2008).

32. Chakraborty, I. \& Pradeep, T. Atomically precise clusters of noble metals: emerging link between atoms and nanoparticles. Chem. Rev. 117, 8208-8271 (2017).

33. Kwak, K., Thanthirige, V. D., Pyo, K., Lee, D. \& Ramakrishna, G. Energy gap law for exciton dynamics in gold cluster molecules. J. Phys. Chem. Lett. 8, 4898-4905 (2017).

34. Jin, R. et al. Size focusing: a methodology for synthesizing atomically precise gold nanoclusters. J. Phys. Chem. Lett. 1, 2903-2910 (2010).

35. Keller, B. O., Sui, J., Young, A. B. \& Whittal, R. M. Interferences and contaminants encountered in modern mass spectrometry. Anal. Chim. Acta 627, 71-81 (2008).

36. Zheng, K., Setyawati, M. I., Leong, D. T. \& Xie, J. Antimicrobial gold nanoclusters. ACS Nano 11, 6904-6910 (2017).

37. Leboffe, M. Microbiology Laboratory Theory and Application (Morton Publishing Company, 2014).

38. Jackson, K. A. et al. Invasive methicillin-resistant Staphylococcus aureus infections among persons who inject drugs - Six sites, 2005-2016. MMWR 67, 625-628 (2018)

39. Kourtis, A. P. et al. Vital signs: epidemiology and recent trends in methicillinresistant and in methicillin-susceptible Staphylococcus aureus bloodstream infections - United States. MMWR 68, 214-219 (2019).
40. Osram L58 W/865 LUMILUX T8, Tubular fluorescent lamps $26 \mathrm{~mm}$, with G13 bases. (OSRAM, 2017).

41. Tortora, G., Funke, R. B. \& Case, L. C. Microbiology; An Introduction. (Addison-Wesley Longman, Inc., 2001)

42. Daoud, W. A., Xin, J. H. \& Zhang, Y.-H. Surface functionalization of cellulose fibers with titanium dioxide nanoparticles and their combined bactericidal activities. Surf. Sci. 599, 69-75 (2005).

43. Itoh, M. et al. Mechanism of chromium(VI) toxicity in Escherichia coli: is hydrogen peroxide essential in Cr(VI) toxicity? J. Biochem. 117, 780-786 (1995).

44. Ghimire, B., Lee, G. J., Mumtaz, S. \& Choi, E. H. Scavenging effects of ascorbic acid and mannitol on hydroxyl radicals generated inside water by an atmospheric pressure plasma jet. AIP Adv. 8, 075021 (2018).

45. Chibli, H., Carlini, L., Park, S., Dimitrijevic, N. M. \& Nadeau, J. L. Cytotoxicity of $\mathrm{InP} / \mathrm{ZnS}$ quantum dots related to reactive oxygen species generation. Nanoscale 3, 2552-2559 (2011).

46. Tsimvrakidis, K. et al. Enhanced optics for time-resolved singlet oxygen luminescence detection. IEEE J. Sel. Top. Quantum Electron. 25, 1-7 (2019).

47. Boso, G. et al. Time-resolved singlet-oxygen luminescence detection with an efficient and practical semiconductor single-photon detector. Biomed. Opt. Express 7, 211-224 (2016).

48. Yang, Z. et al. Constructing $\mathrm{TiO}_{2}$ decorated $\mathrm{Bi}_{2} \mathrm{WO}_{6}$ architectures with enhanced visible-light-driven photocatalytic activity. Semicond. Sci. Technol. 32, 065008 (2017)

49. $\mathrm{Xu}$, J. et al. $\mathrm{BiOCl}$ decorated $\mathrm{NaNbO}_{3}$ nanocubes: a novel $\mathrm{p}$-n heterojunction photocatalyst with improved activity for ofloxacin degradation. Front. Chem. 6, 393 (2018).

50. $\mathrm{Hu}, \mathrm{W}$. \& Yang, J. Two-dimensional van der Waals heterojunctions for functional materials and devices. J. Mater. Chem. C. 5, 12289-12297 (2017)

51. Zhang, G. et al. Energy materials design for steering charge kinetics. $A d v$. Mater. 30, e1801988 (2018).

52. Dunnill, C. W. et al. Nanoparticulate silver coated-titania thin films-Photooxidative destruction of stearic acid under different light sources and antimicrobial effects under hospital lighting conditions. J. Photochem. Photobiol. A 220, 113-123 (2011)

53. Ganguly, P., Byrne, C., Breen, A. \& Pillai, S. C. Antimicrobial activity of photocatalysts: Fundamentals, mechanisms, kinetics and recent advances. Appl. Catal. B 225, 51-75 (2018).

54. Dalrymple, O. K., Stefanakos, E., Trotz, M. A. \& Goswami, D. Y. A review of the mechanisms and modeling of photocatalytic disinfection. Appl. Catal. B 98, 27-38 (2010).

55. Dunnill, C. W., Aiken, Z. A., Pratten, J., Wilson, M. \& Parkin, I. P. Sulfur- and nitrogen-doped titania biomaterials via APCVD. Chem. Vap. Depos. 16, 50-54 (2010).

56. Liu, C. et al. Rapid water disinfection using vertically aligned $\mathrm{MoS}_{2}$ nanofilms and visible light. Nat. Nanotechnol. 11, 1098-1104 (2016).

57. Krishna, V. et al. Contaminant-activated visible light photocatalysis. Sci. Rep. 8, 1894 (2018).

58. Li, J. et al. Light-activated rapid disinfection by accelerated charge transfer in red phosphorus/ZnO heterointerface. Small Methods 3, 1900048 (2019).

59. Noimark, S. et al. Photobactericidal polymers; the incorporation of crystal violet and nanogold into medical grade silicone. RSC Adv. 3, 18383 (2013).

60. Patir, A., Hwang, G. B., Nair, S. P., Allan, E. \& Parkin, I. P. Photobactericidal activity of dual dyes encapsulated in silicone enhanced by silver nanoparticles. ACS Omega 3, 6779-6786 (2018).

61. Bukorović, N. Lighting Guide 2 - Hospitals and Health Care Buildings (Chartered institution of building services engineers, 2008).

\section{Acknowledgements}

The authors thank the EPSRC for financial support (EP/M015157/1) through the Manufacturing Advanced Functional Materials (MAFuMa) scheme. H.H. acknowledges the financial support from a UCL-CSC scholarship.

\section{Author contributions}

G.B.H. designed and performed the experiments and wrote and revised the manuscript E.A., A.G. and I.P.P. designed and supervised experiments and revised the manuscript. H.H. and G.W. synthesised and characterised $\left[\mathrm{Au}_{25}(\mathrm{Cys})_{18}\right]$. K.K. and H.D.T. advised on the synthesis and characterisation of $\left[\mathrm{Au}_{25}(\mathrm{Cys})_{18}\right]$. A.M.A. carried out XPS analysis. A.J M. advised and carried out mechanistic studies. A.K. carried out time-resolved PL measurements. L.M.H. carried out TRNIR microscopy. J.S. carried out XPS, photocurrent measurements and mechanistic studies.

\section{Competing interests}

The authors declare no competing interests. 


\section{Additional information}

Supplementary information is available for this paper at https://doi.org/10.1038/s41467020-15004-6.

Correspondence and requests for materials should be addressed to I.P.P.

Peer review information Nature Communications thanks Adelaide Almeida and Asad Khan for their contribution to the peer review of this work. Peer reviewer reports are available.

Reprints and permission information is available at http://www.nature.com/reprints

Publisher's note Springer Nature remains neutral with regard to jurisdictional claims in published maps and institutional affiliations. (c) (i) Open Access This article is licensed under a Creative Commons Attribution 4.0 International License, which permits use, sharing, adaptation, distribution and reproduction in any medium or format, as long as you give appropriate credit to the original author(s) and the source, provide a link to the Creative Commons license, and indicate if changes were made. The images or other third party material in this article are included in the article's Creative Commons license, unless indicated otherwise in a credit line to the material. If material is not included in the article's Creative Commons license and your intended use is not permitted by statutory regulation or exceeds the permitted use, you will need to obtain permission directly from the copyright holder. To view a copy of this license, visit http://creativecommons.org/ licenses/by/4.0/.

(C) The Author(s) 2020 